\title{
Field workshop on the Ediacaran Nama Group of southern Namibia
}

\author{
21-25 August 2016, Windhoek to Fish River Canyon, Southern Namibia
}
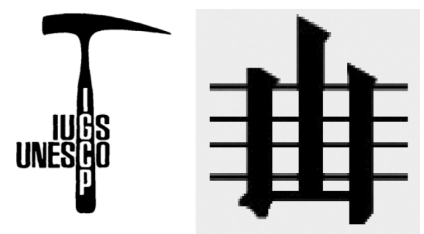

\author{
Shuhai Xiao ${ }^{1 *}$, Patricia Vickers-Rich ${ }^{2}$, Guy Narbonne ${ }^{3}$, Marc \\ Laflamme $^{4}$, Simon Darroch ${ }^{5}$, Alan J. Kaufman ${ }^{6}$, and Les Kriesfeld ${ }^{2}$
}

${ }^{1}$ Department of Geosciences, Virginia Polytechnic and State University, Blacksburg, VA 24061, USA; Chair of ICS Subcommission on

Ediacaran Stratigraphy; *Corresponding author, E-mail: xiao@vt.edu

${ }^{2}$ School of Earth, Atmosphere \& Environment, Monash University, Melbourne 3800, Australia

${ }^{3}$ Department of Geological Sciences and Geological Engineering, Queen's University, Kingston, Ontario K7L 3N6, Canada

${ }^{4}$ Department of Chemical and Physical Sciences, University of Toronto Mississauga, Ontario L5L 1C6, Canada

${ }^{5}$ Earth \& Environmental Science, Vanderbilt University, Nashville, Tennessee 37235-1905, USA

${ }^{6}$ Department of Geology and Earth System Science Interdisciplinary Center, University of Maryland, College Park, Maryland 20742-4211, USA

Among all established geological periods, the Ediacaran Period is the longest, lasting from $635 \mathrm{Ma}$ to $541 \mathrm{Ma}$. It is within this 94 million years of geological history that the Earth was transformed from a world dominated by microbes to one increasingly influenced by animal activities. Important evolutionary innovations occurred in the Ediacaran Period, including the rise of macroscopic animals, complex ecological interactions, and metazoan biomineralization. Resolving the causes and consequences of these biological innovations is a major focus of recent geobiological investigations. However, without a solid geological time framework, Ediacaran workers are facing significant challenges in assembling the pieces of the puzzle from different parts of the world. To develop a better understanding of Ediacaran time and life, a group of 25 geologists, geochemists, sedimentologists, and paleontologists gathered together to examine the terminal Ediacaran Nama Group at a field workshop sponsored by IGCP 587 "Identity, Facies and Time: The Ediacaran (Vendian) Puzzle" and the ICS Subcommission on Ediacaran Stratigraphy.

The terminal Ediacaran Nama Group near Aus in southern Namibia holds a special place in the history of Ediacaran paleontology. Some of the earliest complex Ediacara-type fossils were first reported from the Nama Group (Gürich, 1929; Fedonkin et al., 2007; Xiao, 2008). This succession contains important geological information about the Shuram carbon isotope excursion (potentially the greatest $\mathrm{C}$-isotope excursion in Earth history), the expansion of animal bioturbation, the rise of animal skeletonization and biomineralization, and the decline and final demise of the Ediacara biota. It is also a key succession to define the Terminal Ediacaran Stage (TES) (Xiao et al., 2016), which has been identified as one of the priorities for the Subcommission of Ediacaran Stratigraphy following a 2014 workshop in South China (Xiao et al., 2014) and a 2015 symposium in Graz, Austria.

Participants were drawn to Namibia by the new developments and discoveries made in the Nama Group in recent years. These include new discoveries and interpretations of Ediacaran and Cambrian fossils (e.g., Narbonne et al., 1997; Jensen et al., 2000; Grazhdankin and Seilacher, 2002; Wood et al., 2002; Grazhdankin and Seilacher, 2005; Jensen and Runnegar, 2005; Elliott et al., 2011; Wilson et al., 2012; Vickers-
Rich et al., 2013; Meyer et al., 2014a; Meyer et al., 2014b; Darroch et al., 2015; Zhuravlev et al., 2015; Darroch et al., 2016; Elliott et al., 2016; Ivantsov et al., 2016), paleoecological investigation of reef-building skeletal fossils (e.g., Penny et al., 2014; Wood and Curtis, 2016), comprehensive geochemical analyses (e.g., Hall et al., 2013; Wood et al., 2015), and much needed radiometric ages from key stratigraphic horizons (Grotzinger et al., 1995). Building upon these advances, several research teams are actively working on the Nama Group in order to further improve our understanding of the late Ediacaran Period.

Before the field workshop officially kicked off, a small group of participants visited the Geological Survey of Namibia to examine its Ediacaran fossil collection, which has been significantly expanded over the past 15 years through IGCP 493/597 and includes the recently reported three-dimensional specimens of Rangea (Vickers-Rich et al., 2013) and Ernietta (Ivantsov et al., 2016). The field workshop started with an examination of classic fossil sites on Farm Aar where ground-breaking discoveries were made in the past. Participants were able to have an up-close look at large Pteridinium slabs assembled by the late Dolf Seilacher, Rangea excavation site published by Vickers-Rich and colleagues, Beltanelliformis excavation site near Ernietta Hill, as well as beds containing new and undescribed forms that are currently under investigation. Lively discussion and debate were heard on the outcrops about the morphology, ecology, taphonomy, and affinity of these enigmatic Ediacara-type fossils. At the lunch break in the Aar farmhouse, a brief ceremony was held to recognize Mrs. Barbara Boehm-Erni as a guardian of this paleontological heritage on her farm. Participants were also able to make a side trip to look at some amazing San petroglyphs on the farm.

On the morning of August 23, participants were shown a section of the Kanies and Mara members at the base of the Nama Group, on Farm Pockenbank some $60 \mathrm{~km}$ south of Aus. The Mara Member is characterized by negative carbon isotope signatures and may be correlated with the Shuram negative carbon isotope excursion in Oman. Emerging data from the Mara Member suggest that anaerobic oxidation of methane may have contributed to the negative carbon isotope signatures seen in this and other Ediacaran units thought to be equivalent to the Shu- 


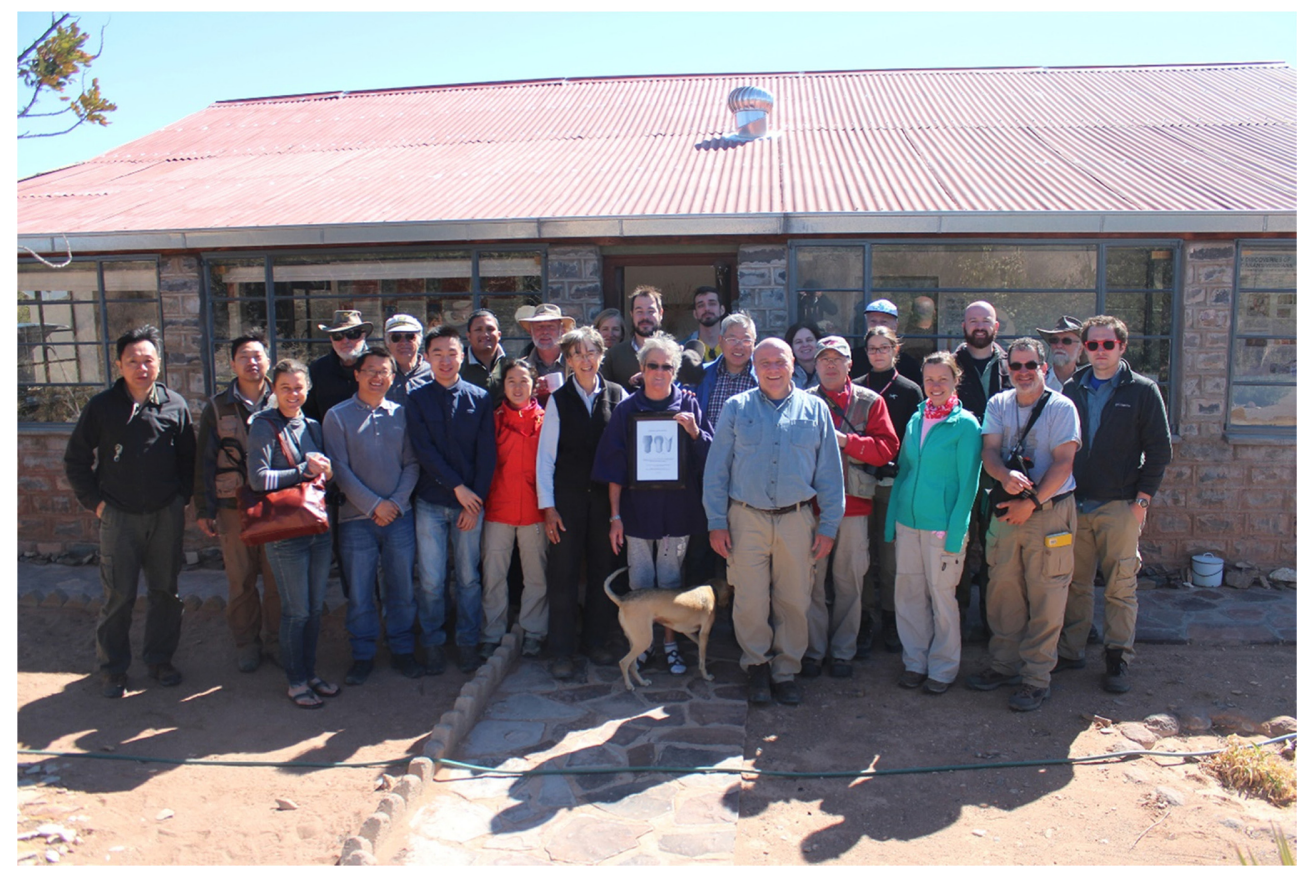

Figure 1. Group picture of participants in the Nama Group field workshop, taken in front of the Aar Farmhouse. From left to right: Pengju Liu, Qing Tang, Andrea Du Plessis, Tom Rich, Ben Yang, Greg Retallack, Xiaodong Shang, Preston (driver), Juliana Okubo, Bernd Roemer, Patricia Vichers-Rich, Angela Ehling, Lucas Warren, Barbara Boehm-Erni, Gabriel Jubé Uhlein, Maoyan Zhu, Guy Narbonne, Doris Honold, Shuhai Xiao, Stuart Clenagham, Stuart Clenagham, Heda Agić, Natasha Bykova, Mike Meyer, Jay Kaufman, Les Kriesfeld, Drew Muscente. Photograph by Jeff Smith.

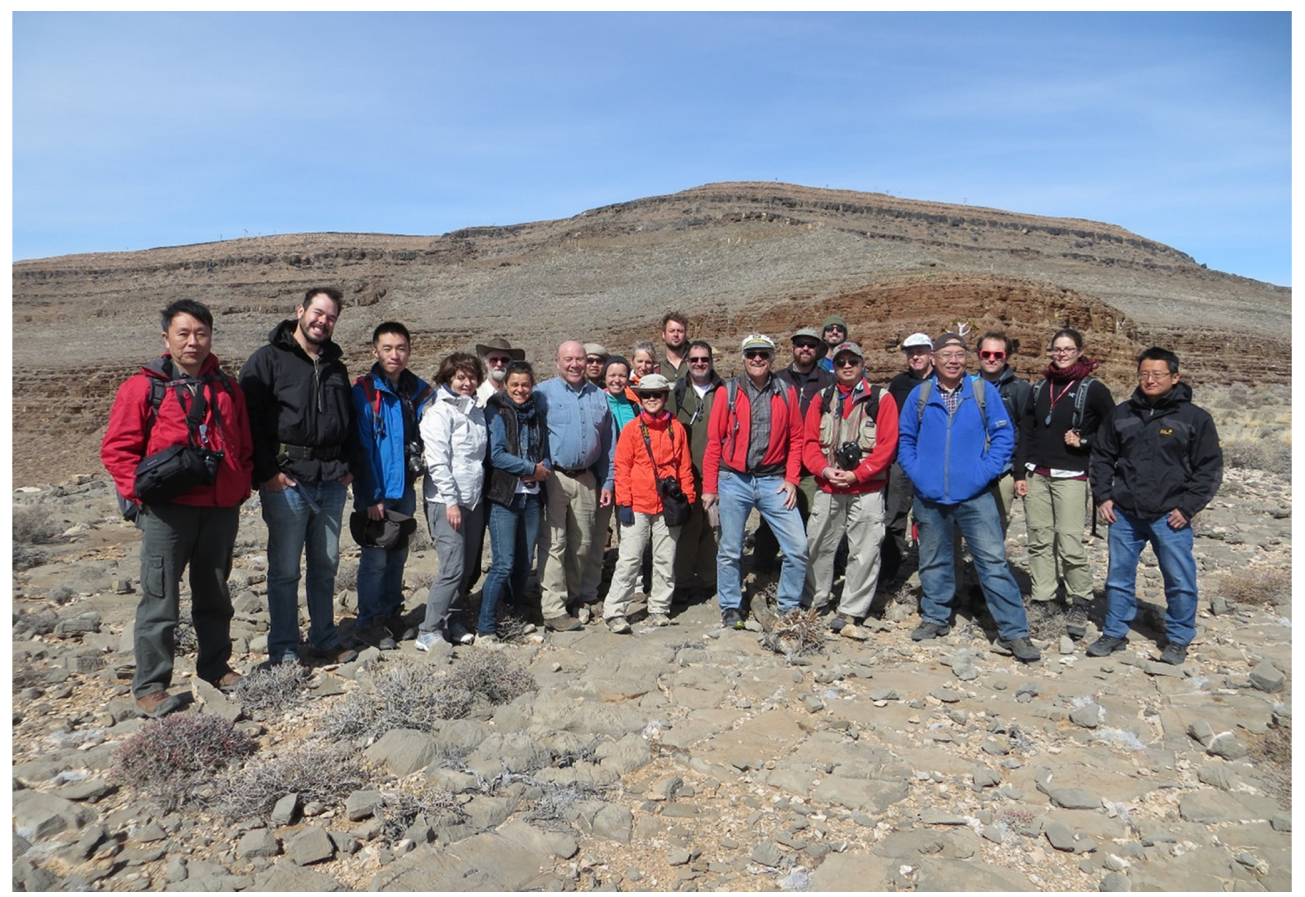

Figure 2. Group picture on outcrops of the Dabis Formation, Farm Pockenbank.

ram excursion. The Mara Member is also reported to host some of the oldest specimens of the biomineralizing animal fossil Cloudina in Namibia and potentially globally. As such, the Mara Member offers a rare opportunity to resolve the relationship between the Shuram excursion and the first appearance of Cloudina, which is critical in defining TES (Xiao et al., 2016). In the afternoon, we jumped to the top of the
Nama Group, observing some of the latest Ediacaran strata of the Spitzkopf Member on Farm Swartpunt. The abundance of trace fossils, soft-bodied Ediacara fossils, thrombolitic microbial buildups, biomineralizing animal fossils such as Cloudina and Namacalathus, and numerous volcanic ash beds in these strata offers an unparalleled opportunity to test hypotheses about the extinction of the Ediacara 
biota (Darroch et al., 2015).

On the last day of the field workshop, some participants ventured to explore the geology and ecology of the Fish River Canyon as well as the geology of hot springs at Ai-Ais, whereas others took a trip to observe the spectacular trace fossils and ancient valley fills in the early Cambrian Nomtsas Formation on Farm Sonntagsbrunn. The field trip ended with a night stay at Fish River Canyon Village, where participate continued their discussion - over traditional Namibian beverages and safari gourmets - on Nama Group stratigraphy and paleontology, as well as plans for future expeditions.

The Nama Group field workshop was followed by a 1.5-day symposium entitled "The Dawn of Animals: Cryogenian to Cambrian" at the $35^{\text {th }}$ IGC in Cape Town. The symposium included 33 oral presentations and 12 poster presentations. During IGC, the Subcommission on Ediacaran Stratigraphy held a business meeting on the evening of August 29, where an announcement was made to elect Andy Knoll and Malcolm Walter as the inaugural honorary members of the Subcommission. Plans for formal designation of the basal and terminal stages of the Ediacaran System are underway (Xiao et al., 2016) and detailed discussion of series-level subdivision will begin with a field excursion to Newfoundland in June 2017.

Whereas the Nama Group records the end game of the Ediacara biota, the Nama Group field workshop will surely start a new chapter in the study of Ediacaran paleobiology and stratigraphy. With lingering questions and unresolved enigmas, many participants have already expressed interest to come back to Namibia in the near future. After all, as the longest geological period, the Ediacaran holds many secrets that will keep geologists busy for decades to come.

\section{References}

Darroch, S.A.F., Boag, T.H., Racicot, R.A., Tweedt, S., Mason, S.J., Erwin, D.H., and Laflamme, M., 2016, A mixed Ediacaran-metazoan assemblage from the Zaris Sub-basin, Namibia: Palaeogeography Palaeoclimatology Palaeoecology, v. 459, pp. 198-208.

Darroch, S.A.F., Sperling, E.A., Boag, T.H., Racicot, R.A., Mason, S.J., Morgan, A.S., Tweedt, S., Myrow, P., Johnston, D.T., Erwin, D.H., and Laflamme, M., 2015, Biotic replacement and mass extinction of the Ediacara biota: Proceedings of the Royal Society B (Biological Sciences), v. 282, no. 1814, pp. 20151003.

Elliott, D.A., Trusler, P.W., Narbonne, G.M., Vickers-Rich, P., Morton, N., Hall, M., Hoffmann, K.H., and Schneider, G.I.C., 2016, Ernietta from the Late Ediacaran Nama Group, Namibia: Journal of Paleontology, v. 90, no. 6, pp. 1017-1026.

Elliott, D.A., Vickers-Rich, P., Trusler, P., and Hall, M., 2011, New evidence on the taphonomic context of the Ediacaran Pteridinium: Acta Palaeontologica Polonica, v. 56, pp. 641-650.

Fedonkin, M.A., Gehling, J.G., Grey, K., Narbonne, G.M., and Vickers-Rich, P., 2007, The Rise of Animals: Evolution and Diversification of the Kingdom Animalia: Johns Hopkins University Press, Baltimore, 326 p.

Grazhdankin, D., and Seilacher, A., 2002, Underground Vendobionta from Namibia: Palaeontology, v. 45, pp. 57-78.

Grazhdankin, D., and Seilacher, A., 2005, A re-examination of the Nama-type Vendian organism Rangea schneiderhoehni: Geological Magazine, v. 142, pp. 571-582.

Grotzinger, J.P., Bowring, S.A., Saylor, B.Z., and Kaufman, A.J., 1995, Biostratigraphic and geochronologic constraints on early animal evolution: Science, v. 270, p. 598-604.

Gürich, G., 1929, Die ältesten Fossilien Sudafrikas: Zeitschrift für Prak- tische Geologie, v. 37, pp. 85-86.

Hall, M., Kaufman, A.J., Vickers-Rich, P., Ivantsov, A., Trusler, P., Linnemann, U., Hofmann, M., Elliott, D., Cui, H., Fedonkin, M., Hoffmann, K.-H., Wilson, S.A., Schneider, G., and Smith, J., 2013, Stratigraphy, palaeontology and geochemistry of the lateNeoproterozoic Aar Member, southwest Namibia: Reflectingenvironmental controls on Ediacara fossil preservation duringthe terminal Proterozoic in African Gondwana: Precambrian Research, v. 238, pp. 214-232.

Ivantsov, A.Y., Narbonne, G.M., Trusler, P.W., Greentree, C., and VickersRich, P., 2016, Elucidating Ernietta: new insights from exceptional specimens in the Ediacaran of Namibia: Lethaia, v. 49, pp. 540-554.

Jensen, S., and Runnegar, B.N., 2005, A complex trace fossil from the Spitskop Member (terminal Ediacaran-? Lower Cambrian) of southern Namibia: Geological Magazine, v. 142, pp. 561-569.

Jensen, S., Saylor, B.Z., Gehling, J.G., and Germs, G.J.B., 2000, Complex trace fossils from the terminal Proterozoic of Namibia: Geology, v. 28, pp. 143-146.

Meyer, M., Elliott, D., Schiffbauer, J.D., Hall, M., Hoffman, K.H., Schneider, G., Vickers-Rich, P., and Xiao, S., 2014a, Taphonomy of the Ediacaran fossil Pteridinium simplex preserved three-dimensionally in mass flow deposits, Nama Group, Namibia: Journal of Paleontology, v. 88, pp. 240-252.

Meyer, M., Elliott, D., Wood, A.D., Polys, N.F., Colbert, M., Maisano, J.A., Vickers-Rich, P., Hall, M., Hoffman, K.H., Schneider, G., and Xiao, S., 2014b, Three-dimensional microCT analysis of the Ediacara fossil Pteridinium simplex sheds new light on its ecology and phylogenetic affinity: Precambrian Research, v. 249, pp. 79-87.

Narbonne, G.M., Saylor, B.Z., and Grotzinger, J.P., 1997, The youngest Ediacaran fossils from southern Africa: Journal of Paleontology, v. 71, pp. 953-967.

Penny, A.M., Wood, R., Curtis, A., Bowyer, F., Tostevin, R., and Hoffman, K.-H., 2014, Ediacaran metazoan reefs from the Nama Group, Namibia: Science, v. 344, pp. 1504-1506.

Vickers-Rich, P., Ivantsov, A.Y., Trusler, P.W., Narbonne, G.M., Hall, M., Wilson, S.A., Greentree, C., Fedonkin, M.A., Elliott, D.A., Hoffmann, K.H., and Schneider, G.I.C., 2013, Reconstructing Rangea: new discoveries from the Ediacaran of southern Namibia: Journal of Paleontology, v. 87 , pp. $1-15$.

Wilson, J.P., Grotzinger, J.P., Fischer, W.W., Hand, K.P., Jensen, S., Knoll, A.H., Abelson, J., Metz, J.M., McLoughlin, N., Cohen, P.A., and Tice, M.M., 2012, Deep-water incised valley deposits at the ProterozoicCambrian boundary in southern Namibia contain abundant Treptichnus pedum: Palaios, v. 27, pp. 252-273.

Wood, R., and Curtis, A., 2016, Extensive metazoan reefs from the Ediacaran Nama Group, Namibia: the rise of benthic suspension feeding: Geobiology, v. 13, pp. 112-122.

Wood, R.A., Grotzinger, J.P., and Dickson, J.A.D., 2002, Proterozoic modular biomineralized metazoan from the Nama Group, Namibia: Science, v. 296, pp. 2383-2386.

Wood, R.A., Poulton, S.W., Prave, A.R., Hoffmann, K.-H., Clarkson, M.O., Guilbaud, R., Lyne, J.W., Tostevin, R., Bowyer, F., Penny, A.M., Curtis, A., and Kasemann, S.A., 2015, Dynamic redox conditions control late Ediacaran metazoan ecosystems in the Nama Group, Namibia: Precambrian Research, v. 261, pp. 252-271.

Xiao, S., 2008, The rise and demise of ghostly animals: Science, v. 319, pp. 1618-1619.

Xiao, S., Narbonne, G.M., Zhou, C., Laflamme, M., Grazhdankin, D.V., Moczydłowska-Vidal, M., and Cui, H., 2016, Toward an Ediacaran time scale: problems, protocols, and prospects: Episodes, v. 39, no. 4, pp. 540-555.

Xiao, S., Zhou, C., and Zhu, M., 2014, International Symposium and Field Workshop on Ediacaran and Cryogenian Stratigraphy: Episodes, v. 37, pp. 218-221.

Zhuravlev, A., Yu., Wood, R.A., and Penny, A.M., 2015, Ediacaran skeletal metazoan interpreted as a lophophorate: Proceedings of the Royal Society B (Biological Sciences), v. 282, pp. 20151860. 